\title{
Surveyor
}

\section{RETIRING ADDRESS: By the President of the Institution of Surveyors}

\section{F. L. Alexander}

To cite this article: F. L. Alexander (1919) RETIRING ADDRESS: By the President of the Institution of Surveyors, Surveyor, 32:1, 3-8, DOI: 10.1080/18324460.1919.10439450

To link to this article: http://dx.doi.org/10.1080/18324460.1919.10439450

曲 Published online: 01 Aug 2012.

Submit your article to this journal ๘

Џ Article views: 3

Q View related articles $\sqsubset$ 


\section{Annual General Meeting.}

The Annual General Meeting was held at the Royal Society's Hall, on Tuesday, January 28 th, I9I9.

The following members attended:-Messrs. P. IV. Rygate, E. H. Cowdery, R. H. Cambage. F I. Alexander, H. F. Halloran II. L. Brothers, J. E. Proust, S R. Dohbie, J. Weingarth, W. L. Rhodes, A. E. Hall, Thos. McDonnough, R. E. Reid. H. F. Busby, H. M. Nash, W. A. Pike and W. A. Chadwick.

The Chairman announced that ajologies had been received from Messrs. J. H. Cardew. F. Poate, Mi. C. Fariell, E. Kenny, R. J. A Roberts, Frank Chajman and H. G. Foxall for unavoidable absence.

The Chairman stated that the Council had approved the nomination of Messrs. Oliver Claude Raymond and T. Walter Raymond as members.

MIr. F... I. Alexander, Hon. Treasurer, then read his financial report which, on the motion of Mr Dobbie, seconded by Mr. Cambage, was adopted.

Mr. Dobbie moved that a hearty vote of thanks be accorded the Hon. Treasurer for his past services, and regretted his resignation. Mr. Cambage seconded the motion, which was carried unanimously.

The retiring President delivered his Annual Report, reviewing the work of the Institution. M.r. F. H. Cowdery then occupied the Presidential Chair and received a cordial welcome.

\section{RETIRING ADDRESS}

\section{By the President of the Institution of Surveyors}

\section{At the Annual. General Melting. held 28ti Jancary, 1919.}

This being our Annual General Meeting, as is the custom I have the honour to address you on matters pertaining to the profession and in particular on those matters that cropped up during last year.

Before so doing I should like to express my personal obligation to those gentlemen who contributed papers and addresses during the past year, and I feel certain that each and every member of the Institution will join with me in that appreciation.

The jast year was one during which there could not have been many successful General Meetings, still we had some very interesting and instructive papers. At the First General Meeting, Lieutenant Cortis, A.I.F., delivered a lecture on " Surveying at the Western Front." Then we had another visitor, Mir. Chas. Hedley, who talked so ably of "Animal and Plant Life at the De; ths of the Sea." A third address was from Mr. Vice-President Cowdery, on "Town Planning." 
In addition there was a General Meeting to receive and discuss the then proposed Scale of Fees.

During the year there were eight Council Meetings, which were universally well attended.

There were six issues of "The Surveyor" during the year, and that journal, 1 believe, maintained its reputation in those issues.

During the year the list of the membershi, has been improved through the addition of ten members, though unfortunately four older members resigned.

Then the number of Honorary Members has been reduced by the demise of the late Professor Gurney, M.A., who occupied for many years the Chair in Mathematics at the Sydney University.

During the last year there were two examinations for Licensed Surveyors, in which eight men were successful. At those examinations the Institution was represented by Mr. Cowdery and myself. Owing to pressure of official duties. Mr. R. H. Cambage (one of our valued members and a Past President of this Institution) resigned his membership of the Board of Examiners. I should like to express my appreciation of the services rendered by Mir. Cambage on that Board. He proved to be an ideal examiner, kindly disposed at all times, though just to his office. Many of our younger members will agree with me when I say that Mr. Cambage at all times proved himself to be a candid but good friend to the students.

Of the many doings during the year, that relating to the new Scale of Fees was about the most important. This compilation necessitated much arduous work, and the Institution is under a big obligation to those members who devoted so much time, etc., to same.

The mention of Scale of Fees forces one to think of those members in the Government Service and to question their salaries. During the year, as President of the Institution, I tendered evidence before the Civil Service Commissioners on two occasions relative to the rate of pay to members of our profession. In my opinion there is room for modification of salaries of Surveyors employed by the Government-to those permanently employed as well as contract men. The highest rating is not commensurate with the work and responsibility. It would appear that the schedule of salaries was drawn up without regard to the services demanded. That these ratings should now stand is absurd, when one considers the increased cost of living. Further, it is about time that a Surveyor's hours of labour when in the field, in the Government employ, should be established. At present it means, in many cases, six days per week, from daylight to dark, and then to receive per hour less than tradesmen's rate of pay.

I trust that those Surveyors in private practice will be able to work loyally to the new Scale of Fees, and that in the near future, with a change in the Commissioners, steps will be seriously taken to prove the value of the services of the members of our Profession who are employed in the Government Serrice.

The matter of Town Planning has taken deeper hold since last addressing you. During the year a very important conference on this subject was held at Brisbane, at which this Institution was represented by our senior Vice-President. Very instructive papers were 
read and discussed. Though the Government appointed a provisional Town Planning Commission, it is unfortunate that there was no member of our profession selected This brought from me, as your President, an appeal, though as yet without result. This Commission is not complete without at least one Surveyor. During this year it is proposed to have a series of lectures on Town Planning, some of which will be technical and no doubt will be of real interest to us as Surveyors.

The Surveyors' Bill was again brought to light during the year, but, after its first reading, nothing more was accomplished. Many members of the Council took much interest in trying to secure further consideration of the Bill, but, alas! to no purpose. However, I shall be more than disappointed if we are not to have the Bill a matter of Law during rgI9.

There was a very serious design to dispense with the services of many Surveyors under the Metropolitan Board of Water Supply and Sewerage during last year. At the investigation of this proposal I (as your President) gave evidence on behalf of the Surveyors affected. These outbursts of retrenchment are not conducive to good work, as capable men will shun the service. Further, to dispense with the services of men trained by the Department in its work is to lose very valuable assets to ratepayers, and should not be countenanced. Unfortunately, the results of the enquiry came too late-certain of the men had permanently left Sydney, others had taken on other work, and others are now in private practice.

Owing to the tightening of the money market, retrenchment in the Lands Department has been effected, in that the Trigonometrical and Geodetic Survey work has been at least suspended. Your Council deemed this a step in the wrong direction, and deputed Mr. S. I. Dobbie; a Past-President, to tender evidence in this matter before Investigating Commissioner Allard. Mr. Dobbie's evidence has appeared in " The Surveyor," and it is to be hoped that New South Wales will still maintain and prosecute a proper National Survey.

There are many important subjects with which we Surveyors should have. clearer light. For example, we should know more about the discharge of flow-off after rainfall. It is not uncommon to he in conflict with municipal authorities as to the size of necessary culverts to take off rainfall. There are many authorities on the subject, many varying formula, some having no regard to slope, others do not regard intensity of rainfall, etc. I should like to hear of some members of this Institution making records on this subject. We have many opportunities of knowing a catchment area, the shape of the area, nature of the surface soil, whether timbered or grassed or cultvated, whether densely occupied, with metalled roads or otherwise. Then, why not give a helping hand to the men who will follow by recording discharges therefrom!. The velocity of approach is a very important factor in the designing of a sufficient culvert. . To somewhat influence my idea of what we should do, I shall be pleased to give $£ 55 \mathrm{~s}$. to the incoming Council to be awarded as a prize for the member writing the most practical 
paper on actually-observed rainfall discharges from small areas, say up to roo acres. The observations need not be restricted to a City nor to a Suburban area.

Then there is a very important matter of Specification writing and the drawing up of Contracts. We are constantly doing this class of work, and as yet I have not seen a Specification for road-making or culvert-building which I can use as a standard. I should like to suggest a paper on these subjects.

In the early days of this Institution much information was given to at least the younger members by debating the methods of drawing up a concise description of an area of land.

Then there are the questions of valuation and arbitration. We should not fail to be versed in these subjects. In the matter of Crown Lands the valuations for alienation, etc., are made by Surveyors, and there is no reason why the valuations thereafter should not be better understood by a Surveyor than by a rent collector.

I cannot allow the present opportunity to pass without expressing great joy at the successful termination of the late horrible war. May there be no more wars, is my fervent prayer.

The proposed Roll of Honour has not been overlooked. Each member should endeavour to have our list exact and complete.

It is a source of deep regret that there are members who refuse to do their duty to the Institution by failing to pay their annual subscription of one guinea. A member once elected is liable for the annual subscription until his resignation is accepted. Were funds available, we could largely expand the work of the Institution, offer prizes for essays, have frequent social gatherings, and in other ways help to make the Institution more worthy of the Profession.

In conclusion. I have to thank the retiring Council for loyal support. I regret that Mr. Harrison did not take office in the new Council. We are losing Mr. Alexander, who for years was our Treasurer. We heartily thank both of those retiring Councillors for the many years of work given to us.

I have to thank the Editors of "The Surveyor" for the continued success, and may each issue continue to be as acceptable as those of the past.

I should not like to forget that we owe Mr. Cutting more than a passing allusion for his untiring efforts to make this Institution a success.

It is now my pleasure to announce the following to be the Officers of the Council for the ensuing year :-

Past-President (ex-officio Member of Council): Philip) W. Rygate, M.A., B.E., Assoc.M.Inst.C.E.

President : Mr. E. H. Cowdery.

Vice-Presidents : Mr. J. H. Cardew, MI.Inst.C.E. ; Mr. J. Weingarth. Hon. Secretary : Mr. William A. Chadwick.

Hon. Treasurer: Mr. F. Hardy.

Editors of "The Surveyor" : Mr. J. E. Proust; Mr. H. G. Foxall, B.E. Business lianager: Mr. Thos. MicDonnough. 
Councillors: Messrs. S. F. Arnheim, A. D. Craig, B.A., B.E., Assoc. M.Inst.C.E., S. R. Dobbie, M. C. Faviell, A. E. Hall, R. E. Reid. Auditors: Frank Chapman, H. F. Busby.

Secretary: S. H. Cutting.

Before installing Mr. Cowdery as the President for the ensuing year, I should like to express my continued faith in the Institution. I thank you once again for having honoured me by electing me as President. Upon my retirement I am conscious of two facts : First, that no man wishes the Institution a greater success than I; and secondly, that as a President I did not at all times reach the high example set by many of my predecessors.

The President, Mr. E. H. Cowdery, on taking the chair, said that he greatly appreciated the honour his brother Surveyors had conferred on him in placing him in the position as head of the Profession for the year. He paid a tribute to the ability and industry of the retiring President, Mr. P. W. Rygate, who had for two years most worthily upheld the dignity of his position. The work of President was no sinecure, as he could say from having been associated with him in very many matters relating to the work and benefit of the members. He would be very glad to receive during the coming year the very valuable advice he hnew he could command from the retiring President.

In seconding the vote of thanks to the President for his address, Mr. R. H. Cambage said that he heartily supported the remarks made by Mr. Cowdery with reference to Mr. Rygate's efforts during the year on behalf of the Profession. From personal knowledge, he was able to say that Mr. Rygate had been very active in regard to different surveying matters, and had used his best endeavours to have the Surveyors Bill passed into law. His chances in this connection had looked good, but pressure of Parliamentary business resulted in the Rill being again held over, and it was hoped his successor would meet with better success. Mr. Rygate in his address had touched upon many points of interest to the Profession, and during his two years of office had earned the best thanks of the Institution.

Mr. F. I.. Alexander, Hon. Treasurer, made the following statement:- The figures speak for themselves. The steady decrease from I906 to I9I4 (the first year of the War) reflects great credit on the Hon. Treasurer's energies, and his resignation must be accepted with regret by all interested in the Institution.

\section{INSTITUTION OF SURVEYORS, NEW SOUTH WALES. (INCORPORATED). \\ Sydney, 28th January: I9r9.}

To the President, Vice-Presidents and Members of the Insti-. tution of Surveyors, New South Wales (Incorf orated). 
Gentlemen,-In resigning from the Honorary Treasurership of this Institution, and handing over the books to my successor, Mr. Hardy, I feel that this step is in the best interests of the Institution, as my distance from town, and many engagements, prevent me from giving the necessary attention to such an important position.

I should now like to place before you a short summary of the operations during the thirteen years of my treasurership.

In 1906 the cash balance was $\mathrm{f}_{\mathrm{I}} 6 \mathrm{I} 8 \mathrm{~s}$. $7 \mathrm{~d}$., and at the close of this financial year it had risen to $f_{3} 33+18 \mathrm{~s}$. 8d., including Commonwealth War Bonds to the value of $£$ I 50 .

\begin{tabular}{|c|c|c|c|c|c|c|}
\hline \multirow[b]{2}{*}{1906} & \multicolumn{2}{|c|}{$\begin{array}{l}\text { Subscriptions Received } \\
\text { for year. }\end{array}$} & \multirow{2}{*}{\multicolumn{2}{|c|}{$\begin{array}{l}\begin{array}{c}\text { Unpaid Subscriptions } \\
\text { for the year. }\end{array} \\
\ldots \quad £ 58 \text { I }\end{array}$}} & \multicolumn{2}{|c|}{$\begin{array}{l}\text { Cost of Journal } \\
\text { after deducting Receipt } \\
\text { for Advertising, etc. }\end{array}$} \\
\hline & .. & EII9 & & & $\cdots$ & $f^{28}$ \\
\hline 1907 & .... & I94 & $\ldots$ & 5.50 & ... & 63 \\
\hline I 908 & ... & 204 & $\ldots$ & 513 & . . & 92 \\
\hline I909 & $\ldots$. & 200 & $\ldots$. & +83 & $\cdots$ & 82 \\
\hline IgIo & $\ldots$. & 219 & .... & 469 & $\ldots$ & 100 \\
\hline I9I I & ... & 225 & $\ldots$ & 480 & .... & 82 \\
\hline I9I2 & $\cdots$ & 232 & $\therefore .$. & 457 & .... & 107 \\
\hline I913 & $\ldots$ & 248 & $\ldots$. & 232 & $\ldots$ & 86 \\
\hline IgI 4 & $\ldots$ & 232 & $\ldots$. & 272 & $\ldots$ & 115 \\
\hline I9I 5 & $\ldots$ & I97 & $\ldots$. & $35^{2}$ & .... & $\mathrm{II}_{4}$ \\
\hline I9I6 & $\ldots$ & 212 & $\ldots$ & 433 & .... & 93 \\
\hline IgI7 & $\ldots$ & I68 & ... & 421. & $\ldots$ & 83 \\
\hline IgI 8 & $\ldots$ & I96 & $\ldots$. & $40 I$ & $\ldots$. & 72 \\
\hline
\end{tabular}

Shortly, the average receipts for subscriptions covering the period was $£ 203$ ros. per annum, and the average amount unpaid at the end of each year $£ 434 \mathrm{r} 5 \mathrm{~s}$. The average nett cost of publishing the Journal was $£ 86$ per annum.

From the Balance Sheet presented herewith it will be seen that the receipts and expenditure for the year are practically the same. and this result is largely due to the attention given to the affairs of the Institution by our Secretary, Mr. Cutting. and I wish to take this opportunity of thanking that gentleman for all the assistance given me during my term of office.

$$
\begin{gathered}
\text { F. L. ALEXANDER, } \\
\text { Hon. Treasurer. }
\end{gathered}
$$

